\title{
Effect of biochar amendment on morphology, productivity and water relations of sunflower plants under non-irrigation conditions
}

\author{
Marina Paneque, José M. De la Rosa *, Juan D. Franco-Navarro, José M. Colmenero-Flores, Heike Knicker \\ Instituto de Recursos Naturales y Agrobiología de Sevilla, Consejo Superior de Investigaciones Científicas (IRNAS-CSIC), Reina Mercedes Av. 10, 41012-Seville, Spain
}

\section{A R T I C L E I N F O}

\section{Article history:}

Received 15 March 2016

Received in revised form 19 July 2016

Accepted 20 July 2016

Available online $\mathrm{xxx}$

\section{Keywords:}

Organic amendment

Mediterranean climate

Water availability

Physiological parameters

Soil properties

Biochar

\begin{abstract}
A B S T R A C T
Three biochars (B1: pine wood, B2: paper-sludge, B3: sewage-sludge) produced under controlled pyrolysis conditions and one produced in kilns (B4: grapevine wood) were used as organic ameliorants in a Calcic Cambisol, which represents a typical agricultural soil of the Mediterranean region. This field study was performed with plants of sunflower (Helianthus annuus L.) at the experimental station "La Hampa", located in the Guadalquivir river valley (SW Spain). The soil was amended with doses equivalent to 1.5 and $15 \mathrm{t}^{-1}$ of the four biochars in two independent plantations. In addition, un-amended plots were prepared in both experiments for comparison purposes. The major goal of this study was the assessment of the effect of biochar amendment on the physiology and development of sunflower plants at field conditions. During most of the growing period plants of un-amended and amended plots showed no stress symptoms either by their appearance or by stress-sensitive biochemical parameters such as the stability of the photosystem II (QY). Biochar addition had no effect on seed germination. Addition of $1.5 \mathrm{t} \mathrm{ha}^{-1}$ biochar did not significantly change the $\mathrm{pH}$ of the soil, its electrical conductivity (EC) or its water holding capacity (WHC). Concomitantly the plant development and plant biomass production remained unaltered. Amendments with $15 \mathrm{t} \mathrm{ha}^{-1}$ slightly increased the WHC of the soil but showed no lasting impact on the soil pH. It stimulated plant growth and led to a greater leaf area, larger plant stems and wider inflorescences of the sunflower plants than those cultivated on the un-amended soil. At the end of the experiment, biochar amendment of soil caused no significant increase of the total biomass production excepting B4, the biochar with the lowest capacity of water retention, which exhibited the highest vegetative growth and seed production. The lack of rain during the last weeks caused a water shortage in the culture that produced greater QY loss in non-amended plants. Interestingly, better growth of amended plants during the drought period correlated with higher reduction of stomatal conductance, indicating that the greater water use efficiency is at the origin of the better crop performance of biochar-amended plants. This finding points to the agronomic relevance of biochar amendment of Mediterranean rain fed crops.
\end{abstract}

(C) 2016 The Authors. Published by Elsevier B.V. This is an open access article under the CC BY-NC-ND license (http://creativecommons.org/licenses/by-nc-nd/4.0/).

\section{Introduction}

Biochar is produced through the pyrolysis (thermal degradation under oxygen limited conditions) of biomass. It has been suggested as a soil conditioner to enhance plant growth by supplying and, more importantly, retaining nutrients and by improving soil physical and biological properties (Downie et al., 2009). As a C-rich material with a low turnover time, its application to soil is expected to significantly increase soil organic matter (SOM) contents, especially the slow SOM pool, while improving the quality of degraded soils (Lehmann and Joseph, 2009, 2015 and Liu et al., 2014). In many regions of the world, SOM is in critical decline. This problem is of particular interest in the case of agricultural areas in Mediterranean countries due to factors such as, overgrazing, intense agriculture and fire frequency (Almendros and González-Vila, 2012; Romanya and Rovira, 2011). Thus, amendment of

\footnotetext{
* Corresponding author.

E-mail address: jmrosa@irnase.csic.es (J.M. De la Rosa).
}

soils with biochar may be an option to fight against further desertification. Concomitantly it enhances soil productivity since this approach has been found to improve soil fertility, which decreases fertilizer requirements (Lehmann et al., 2006; Sohi et al., 2010; De la Rosa et al., 2014 and Zhao et al., 2014). However, the effectiveness of biochar for enhancing plant production depends not only on soil type, climate and type of crop (Blackwell et al., 2009 and Obia et al., 2016) but also on the properties of the biochar (Van Zwieten et al., 2009; Cayuela et al., 2014 and Jeffery et al., 2011). The inherent variability of biochars due to different feedstock and production conditions implies a high variability of their effect on soil properties and productivity (Novak and Busscher, 2013 and Zaho et al., 2013). As a result, the effects of biochar on crop production are rather variable (Borchard et al., 2014; Jeffery et al., 2011, 2015a and Schultz and Glaser, 2012).

There is a lack of information on the effects of biochar on soil physical properties under field conditions in conjunction with crop development and plant yields (Mukherjee et al., 2014) and most of the published data derive from experiments in tropical, subtropical and 
temperate climatic zones. The effects of biochar application on crop cultivation in the Mediterranean region with its dry and hot summers and its typical calcareous soils are not well understood yet. De la Rosa et al. (2014) investigated the relationship between the characteristics of biochars from different feedstock and their effect as ameliorant on a calcic Cambisol. However that study consisted of a short-term pot experiment under controlled greenhouse conditions and optimal irrigation. Genesio et al. (2015) reported the increase of vineyard productivity at biochar amended soils from Tuscany. In addition, Vaccari et al. (2015) showed that the application of $14 \mathrm{t} \mathrm{ha}^{-1}$ of biochar to a tomato plantation with drip irrigation stimulated plant growth. Nevertheless, the necessity of data from field experiments providing specific attention to the effects of biochar amendment on plant physiology is clear.

One of the most important non-irrigated crop in Southern Europe is sunflower (Helianthus annuus L.). In Spain, the average surface of arable soils devoted to its cultivation comprises around $800,000 \mathrm{ha} \mathrm{yr}^{-1}(10 \%$ in irrigated lands) which accounts for a total production of approximately 1,000,000 $\mathrm{t} \mathrm{yr}^{-1}$ (Magrama, 2015). In spite of this, studies on the impact of biochar on this crop are scarce. Whereas Tatarková et al. (2013) reported no positive effect of biochar on the growth of sunflowers, Alburquerque et al. (2014) described an increased plant production for very high application rates of ash-rich biochars, both studies were carried out in irrigated pots under controlled greenhouse conditions.

Most of the studies on biochar effects on plant growth focus on the analysis of total biomass production. However, for a better understanding of how plant growth can be affected, it is necessary to explore other parameters that are indicative of the physiological status of the plant. For instance, Abiven et al. (2015) reported a significant increase in the maize branching due to biochar addition. Given that we are exploring in this study the effects of biochar on plants cultivated under water shortage conditions, physiological parameters including leaf transpiration and the efficiency of photosystem II (PSII) have been determined to reveal the impact of biochar on plant health and plant water status. Quantum yield (QY) is a well-known plant-stress marker that quantifies the Photosystem II (PSII) efficiency. Presently very few reports are available where these parameters have been tested (Kammann et al., 2011 and Alburquerque et al., 2013).

Therefore, the major goal of the present work was to assess the effect of the soil amendment with biochar produced from diverse feedstock (conifer chip-wood, pulp paper sludge, sewage sludge and grapevine wood) on germination, plant growth and productivity, as well as stress and water parameters, in sunflower plants grown in field conditions under non irrigation regime in a Calcic Cambisol (WRB, 2007), a typical Mediterranean soil from the Guadalquivir river valley in Andalusia, Southern Spain. This study also intends to show the usefulness of innovative physiological parameters as a tool to evaluate the effect of biochar amendment on the plant development and to understand how it is affected by biochar characteristics.

\section{Materials and methods}

\subsection{Biochar samples}

Three of the four biochars used in this experiment were provided by the COST action TD1107 "Biochar as option for sustainable resource management". A detailed description of the pyrolysis conditions and nature of the feedstock are provided in Bachmann et al. (2016). Briefly, they were produced by fast pyrolysis (pyrolysis temperature 500$620{ }^{\circ} \mathrm{C} ; 20$ min pyrolysis time) from pine wood (B1), paper-sludge (B2), sewage sludge (B3). The fourth biochar derived from grapevine wood (B4) and was produced by the company "Bodegas Torres" (Spain) applying the traditional kiln technique. A more detailed description of the production conditions, the feedstock, and the chemical and physical properties of the four biochars is given in Table 1. All samples were kept in sealed opaque plastic bags and maintained at $4{ }^{\circ} \mathrm{C}$ until they were used to avoid their alteration or microbial degradation.

\subsection{Field experiments and soil characteristics}

Two field experiments were carried out by seeding Helianthus annuus L. in a typical Mediterranean agriculturally managed soil classified as Calcic Cambisol (WRB, 2007). This sandy loam soil is located at the experimental station "La Hampa" of the "Instituto de Recursos Naturales y Agrobiología de Sevilla", in the Guadalquivir river valley (SW Spain; $37^{\circ} 21.32^{\prime} \mathrm{N}, 6^{\circ} 4.07^{\prime} \mathrm{W}$ ), Coria del Río, Seville. Elemental (EA) analysis was carried out by dry combustion in a flash 2000 HT (C, H, N, S) elemental micro-analyzer (Thermo Scientific, Bremen, Germany) at a combustion temperature of $1020^{\circ} \mathrm{C}$. Total nitrogen (TN) and carbon (TC) were measured in triplicated and total organic carbon (TOC) of soils was determined after the removal of carbonates by treating the soils samples with $1 \mathrm{M} \mathrm{HCl}$. Bulk Cambisol contains $21 \mathrm{~g}$ of TC $\mathrm{kg}^{-1}$ of which $10 \mathrm{~g} \mathrm{~kg}^{-1}$ corresponds to TOC, and $1 \mathrm{~g} \mathrm{~kg}^{-1}$ of TN. Soil pH $\left(\mathrm{H}_{2} \mathrm{O}\right)$ is 8.5 and its WHC and ash content are $49 \%$ and $95 \%$, respectively. Those parameters are typical values reported for Cambisols of cultivated lands around the area of Aljarafe which is located within the province of Seville (Mudarra-Gómez, 1988).

All biochar samples were homogenized and oven-dried at $40{ }^{\circ} \mathrm{C}$ for $72 \mathrm{~h}$ before being applied to the soil. In the case of B4, the material was previously homogenized by crushing and sieving $(<1 \mathrm{~cm})$.

On the 20th of February 2014, the first experiment was started by amending the soil with a biochar dose equivalent to $15 \mathrm{t} \mathrm{ha}^{-1}$. For this purpose a plot of $150 \mathrm{~m}^{2}$ of surface was divided into 5 equal areas. Each biochar was moistured (biochar:water, 1:1) and subsequently applied to one of the five section by mixing it with the first $5 \mathrm{~cm}$ of the topsoil. No biochar was applied to the fifth plot-section, since it was used as control. For each treatment, 24 certified seeds of Helianthus annuus L. were planted. On the 4th of March 2014 a second field experiment was initiated by using the same experimental approach as described above, but with a biochar-application rate of $1.5 \mathrm{t} \mathrm{ha}^{-1}$, in order to test the efficiency of a low rate of biochar-application dose under Mediterranean climate conditions. Moisture of the topsoil $(0-5 \mathrm{~cm})$ at seeding time was $22 \%$ and $24 \%$ for the first and second experiment respectively. In both experiments, the number of germinated seeds and living plants were counted during the first 30 days of the trail (in order to assess the effect of the kind and amount of each biochar on the germination of the seeds and on the plant-survival). After 30 days, 12 plants from each plot were carefully removed. The length of the plant stems were recorded periodically for each plant until reaching the maximum height. In addition, at the end of the experiment (132 and 140 days after seeding (DAS) for $1.5 \mathrm{t} \mathrm{ha}^{-1}$ and $15 \mathrm{tha}^{-1}$ respectively) the number of leaves was counted and the total leaf area (LA) was calculated by non-destructive measurements as described in Rouphael et al. (2007). Data are expressed in $\mathrm{cm}^{2}$.

The heads of the sunflowers were harvested, dried in a forced-air oven $\left(72 \mathrm{~h}\right.$ at $\left.65^{\circ} \mathrm{C}\right)$ and weighted. The seeds produced by each plant were manually separated from the heads, dried in an oven $\left(65^{\circ} \mathrm{C}\right.$; $72 \mathrm{~h}$ ) and then weighted for assessing the sunflower-seed production. At the beginning and at the end of the experiment $\left(t_{0}\right.$ and $t_{f}$ respectively), WHC, $\mathrm{pH}\left(\mathrm{H}_{2} \mathrm{O}\right)(1: 2.5)$ and EC of the soils were analyzed.

From the 20th of February until the 30th of April 2014 the total precipitation of rain accumulated to $150 \mathrm{~L} \mathrm{~m}^{2}$, whereas from the 1 st of May until the 15 st of July 2014 it accounted only for $20 \mathrm{~L} \mathrm{~m}^{2}$. The average temperature increased gradually during the experiment. Due to different climatic conditions during the initial growing phase of the plants in experiment 1 and 2, the plant productivity of the plots with different biochar amendment doses were not compared directly. Therefore, the comparison was performed by relating the effect induced by the biochar to the result of the plants growing on the respective control plot (un- 
amended). Further information on the climatic conditions of the area during the experiment is included in the Supplementary Table (ST1).

\subsection{Laboratory analysis of soils}

Alteration of the soil $\mathrm{pH}$ and EC were measured in triplicates in the supernatant of a 1:2.5 weight:volume mixture of soil and water by using two CRISON glass electrodes (pH Basic 20 and EC-metro Basic 30 respectively). The WHC was determined in triplicate according to Veihmeyer and Hendrickson (1931) by placing $6 \mathrm{~g}$ of each sample over a filter paper (Whatman 2) into a funnel. After saturation of the samples distilled water and letting the covered funnels stand for $12 \mathrm{~h}$ the moist weight of the sample was calculated considering the weight of the funnel and the filter paper. The weight difference between the sample before and after water addition and settling for $12 \mathrm{~h}$ yielded the maximal WHC. It is expressed as the percentage relatively to the total dry weight of the sample.

\subsection{Plant physiology parameters}

\subsubsection{Efficiency of Photosystem-II}

Chlorophyll fluorescence in light-adapted plants was measured using a portable fluorometer (FluorPen FP-100; Photon System Instru-

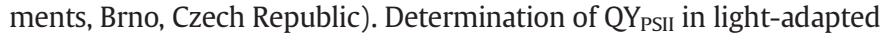
plants was calculated according to Maxwell and Johnson (2000). For each determination, three readings were measured from each leaf and averaged; three leaves from each plant and six plants per treatment were monitored at 90 to 100 DAS in $1.5 \mathrm{t} \mathrm{ha}^{-1}$ treated plants, and 105 to 115 DAS in $15 \mathrm{t} \mathrm{ha}^{-1}$ treated plants.

\subsubsection{Stomatal conductance (leaf transpiration)}

Leaf gas-exchange measurements were conducted by using the Decagon Leaf Porometer (Decagon Devices Inc., Pullman, WA, USA) to determine the stomatal conductance $\left(\mathrm{g}_{\mathrm{s}} ; \mathrm{mmol} \mathrm{H}_{2} \mathrm{O} \mathrm{m}^{-2} \mathrm{~s}^{-1}\right)$ for each experiment (biochar amended and un-amended plants), three photosynthetic active and fully expanded leaves from 6 plants were monitored between $12: 00$ and $14: 00 \mathrm{~h}$ at 90 to 100 DAS in plants from $1.5 \mathrm{t} \mathrm{ha}^{-1}$ experiment, and 105 to 115 DAS for $15 \mathrm{t} \mathrm{ha}^{-1}$ amended plants.

Efficiency of PSII (QY $\mathrm{PSII}_{\text {II }}$ ) and leaf transpiration $\left(\mathrm{g}_{\mathrm{s}}\right)$ measurements were carried out at field in full sunlight, not under cloudy or partly cloudy conditions, during the measurements the mean minimum and maximum temperatures were $26^{\circ} \mathrm{C}$ and $39{ }^{\circ} \mathrm{C}$ respectively, and the relative humidity of air between 25 and 50\% (EL-1-USB Data-logger, Lascar Electronics Inc., Erie, PA, USA). Both parameters (in each dose) were recorded in two different days, with a spacing of ten days, which corresponded to the period after anthesis of plants and full maturity of these. No rainfall event occurred during that period of time (90 to 115 DAS).

\subsection{Statistical analysis}

Data corresponding to plant growth, productivity and physiological parameters are presented as mean values \pm standard error (SE) of single measurements made at field in six different plants of each plot. Soil parameters ( $\mathrm{pH}, \mathrm{WHC}, \mathrm{EC}$ ) are shown as mean values \pm SE of triplicate measurements.

To verify the normality of the data sets Shapiro-Wilk (W) test was used. When response variables were non-normal, Kruskal-Wallis followed by Mann-Whitney U tests were conducted. Normal distributed response variables were analyzed by ONE-WAY ANOVA followed by Tukey's Honestly Significant Difference test (HSD) and Multiple Range Test (MRT) to analyze multiple comparisons between homogenous groups. The level of significance used was 0.05 . All statistical analysis were carried out using SPSS version 17.0 (SPSS, Chicago, IL, USA) and the STATGRAPHICS Centurion XVI software (http://www.statgraphics. com; StatPoint Technologies, Warrenton, VA).

\section{Results and discussion}

\subsection{Impact of biochar amendment on soil pH, EC and WHC}

Table 1 shows the values of soil $\mathrm{pH}$, EC and WHC for each biochar and application dose. Despite the highly alkalinity of B1, B2 and B4 $(\mathrm{pH} \geq 10)$, biochar addition of $1.5 \mathrm{t} \mathrm{ha}^{-1}$ barely altered the soil $\mathrm{pH}$ along the experiment. Amendments with a dose of $15 \mathrm{tha}^{-1}$ of wood biochars (B1 and $\mathrm{B} 4$ ) resulted in a slight increase of the $\mathrm{pH}$ from $8.54 \pm 0.07$ of control soil to about $8.74 \pm 0.01$, which is comparable to the result reported by Schultz et al. (2013) for wood-biochars. On the contrary, B2 and B3 reduced the soil pH to $8.41 \pm 0.01$ and $8.13 \pm 0.01$, respectively. Nevertheless, the Calcic Cambisol showed a high buffering capacity and thus, at the end of the experiment $\left(t_{f}\right)$ the $\mathrm{pH}$ values of the treated soils were comparable to those of the control soil $(8.38 \pm 0.17)$. This result indicates that the biochars had no additional liming effect, which could be critical in already alkaline soils. Similar findings were achieved by De la Rosa et al. (2014) for a biochar amended Calcic Cambisol incubated under greenhouse conditions.

Concerning soil EC, comparable to the $\mathrm{pH}$, the addition of $1.5 \mathrm{tha}^{-1}$ of biochar did not modify significantly this parameter at $t_{0}$, which is in line with results reported by Jones et al. (2011) for a field trial. The increase of the biochar dose to $15 \mathrm{tha}^{-1}$ enhanced soil EC for B2 and B3 amendments at $t_{0}\left(179 \pm 2\right.$ and $195 \pm 3 \mu \mathrm{sm}^{-1}$ respectively). This was probably due to their high ash contents (De la Rosa et al., 2014). Comparable observations were reported by Hossain et al. (2011), who showed a significant rise of the soil EC after addition of biochar produced from a mineral matter rich sewage sludge. The EC depends on the total content of dissolved salts in the solution. However, excessive salt concentration may have an adverse effect on plant health since the salt can be accumulated in the crop root-zone that can affect

Table 1

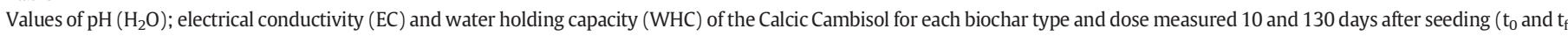
respectively).

\begin{tabular}{|c|c|c|c|c|c|c|c|c|c|c|c|c|}
\hline \multirow[b]{2}{*}{ Sample } & \multicolumn{4}{|c|}{$\mathrm{pH}\left(\mathrm{H}_{2} \mathrm{O}\right)$} & \multicolumn{4}{|c|}{$\mathrm{EC}^{\mathrm{a}}\left(\mathrm{H}_{2} \mathrm{O}\right)\left[\mu \mathrm{cm}^{-1}\right]$} & \multicolumn{4}{|c|}{$\mathrm{WHC}^{\mathrm{b}}[\%]$} \\
\hline & $\overline{t_{0}}$ & S.D. ${ }^{\mathrm{c}}$ & $t_{f}$ & S.D. & $\overline{t_{0}}$ & S.D. & $t_{f}$ & S.D. & $\overline{t_{0}}$ & S.D. & $t_{f}$ & S.D. \\
\hline Control (un-amended) & 8.54 & \pm 0.07 & 8.38 & \pm 0.17 & 134 & \pm 25 & 155 & \pm 16 & 50.1 & \pm 0.7 & 52.6 & \pm 4.0 \\
\hline $1.5 \mathrm{t} \mathrm{ha}-1$ & 8.50 & \pm 0.00 & 8.43 & \pm 0.01 & 121 & \pm 1 & 129 & \pm 8 & 52.6 & \pm 0.3 & 50.1 & \pm 2.6 \\
\hline$\overline{\mathrm{B} 2}$ & 8.36 & \pm 0.01 & 8.41 & \pm 0.00 & 150 & \pm 2 & 129 & \pm 0 & 51.7 & \pm 3.6 & 50.9 & \pm 2.9 \\
\hline B3 & 8.48 & \pm 0.02 & 8.43 & \pm 0.01 & 120 & \pm 1 & 184 & \pm 3 & 52.8 & \pm 5.0 & 51.8 & \pm 4.2 \\
\hline B4 & 8.44 & \pm 0.01 & 8.37 & \pm 0.03 & 135 & \pm 2 & 139 & \pm 3 & 52.9 & \pm 0.3 & 49.8 & \pm 1.6 \\
\hline $15 \mathrm{t} \mathrm{ha}-1$ B1 & 8.74 & \pm 0.01 & 8.35 & \pm 0.02 & 137 & \pm 3 & 201 & \pm 24 & 55.8 & \pm 4.4 & 56.1 & \pm 3.7 \\
\hline$\overline{\mathrm{B} 2}--$ & 8.41 & \pm 0.01 & 8.29 & \pm 0.01 & 179 & \pm 2 & 164 & \pm 2 & 56.3 & \pm 2.9 & 55.9 & \pm 4.3 \\
\hline B3 & 8.13 & \pm 0.01 & 8.28 & \pm 0.01 & 195 & \pm 3 & 180 & \pm 4 & 49.5 & \pm 1.8 & 51.0 & \pm 3.8 \\
\hline B4 & 8.72 & \pm 0.00 & 8.37 & \pm 0.00 & 137 & \pm 2 & 210 & \pm 2 & 55.7 & \pm 0.6 & 53.5 & \pm 1.9 \\
\hline
\end{tabular}

${ }^{a}$ EC: Electrical conductivity; ${ }^{\mathrm{b}}$ WHC: Water Holding Capacity; ${ }^{\mathrm{c}}$ S.D.: Standard Deviation; $\mathrm{t}_{0}$ and $\mathrm{t}_{\mathrm{f}}$ : 10 and 130 days after seeding respectively. 
water and nutrient uptake by the plants and therefore the crop yield. In addition, the mobilization of excess salt can have negative off-site environmental impacts, which also have to be borne in mind if ash-rich biochars are used. Anyway, the EC values reported here are lower than the threshold of $270 \mu \mathrm{sm}^{-1}$ recommended for most crops including sunflower (EPA, 1991) and far below the EC value of saline soils ( $\geq 2000 \mu \mathrm{sm}^{-1}$; Soil survey division staff, 1993). In comparison with the starting values $\left(\mathrm{t}_{0}\right)$, the EC observed for B2 and B3 at $\mathrm{t}_{\mathrm{f}}$ decreased slightly (from $179 \pm 2$ to $164 \pm 2$ and from $195 \pm 3$ to $180 \pm$ $4 \mu \mathrm{sm}^{-1}$ respectively), which is probably due to partial leaching. At $t_{f}$, the EC of the rest of soils increased compared with $t_{0}$ (B1: $137 \pm 3$ to $201 \pm 24 \mu \mathrm{sm}^{-1}$ and B4: $137 \pm 2$ to $210 \pm 2 \mu \mathrm{cm}^{-1}$ ). Li et al. (2013) attributed this behavior to the release of fused-ring aromatic structures from biochar, which could be related with the high aromaticity and abundance of polycyclic aromatic hydrocarbons of both (B1 and B4) wood biochar samples (De la Rosa et al., 2016).

Several authors reported increases of WHC due to biochar amendment (Laird et al., 2010 and Uzoma et al., 2011). However, this parameter strongly depends among other properties on the applied biochar dose or its OC content. The application of a dose of $1.5 \mathrm{t}$ biochar ha ${ }^{-1}$ did not significantly increase the WHC of the soils. Biochar amendment at dose of $15 \mathrm{tha}^{-1}$, on the other hand, caused a relative increase of WHC up to $7 \%$, leading to a value of $56.3 \pm 2.9 \%$ for the soils with B2 (WHC of control soil $=50.1 \pm 0.7$ at $\mathrm{t}_{0}$ ). Addition of $\mathrm{B} 3$ resulted in no significant increase of the WHC. This is related to its low OC content ( $<20 \%$; De la Rosa et al., 2014). In fact the differences observed between the four biochars are not significant, which is in accordance with Jeffery et al. (2015b) and Ojeda et al. (2015) who reported no effect of biochar addition on WHC.

\subsection{Effects of biochar amendment on sunflower germination, growth and crop productivity}

\subsubsection{Seed germination}

Table 2 shows the percentages of emerged sunflower plants for both experiments. Biochar amendment did not modify the germination rates of sunflower seeds. In all cases germination rates remained around $90 \%$. A comparable result was reported for seeds of Lolium perenne L. which were grown in pots on a biochar amended Calcic Cambisol with optimal water irrigation under greenhouse conditions (De la Rosa et al., 2014). Alburquerque et al. (2014) reported a significant increase of germination efficiency with the increase in the amount of biochar in greenhouse pot experiments. This increase was found to depend highly on the $\mathrm{pH}$ of the soil $(r=0.73 ; p<0.001)$. In our case, the $\mathrm{pH}$ of the alkaline Cambisol was not significantly modified due to biochar addition, neither were the seed germination rates.

\subsubsection{Plant development}

None of the biochar type caused significant effects on stem length or stem diameter of the sunflowers at $1.5 \mathrm{t} \mathrm{ha}^{-1}$ application rate (Fig. 1a and Table 2). At this dose, the diameters of sunflower heads remained practically unaltered, except a small decrease observed after amendment of B2 and B1 (Table 2).

In contrast, differences were observed with respect to the growth responses at $15 \mathrm{t} \mathrm{ha}^{-1}$ application rate (Fig. 1b). Data recorded 60 days after seeding (DAS) revealed significantly longer stems of plants growing on biochar amended soils than of those planted developing on nonamended plots, nevertheless there were no significant differences with respect to the type of biochars.

At 100 DAS the differences between the control and biochar amended plots were reduced until being statistically insignificant, with the exception of the plots treated with B4, which produced the longest plant stems. This trend remained unaltered until the last measurement. Consequently, in comparison to the control, B4 applied at a dose of $15 \mathrm{tha}^{-1}$ was the only treatment causing a significant increase of the stem length (Fig. 1). Compared to the $1.5 \mathrm{t} \mathrm{ha}^{-1}$ biochar dose, the stem diameter measured at the maximum stage of plant development increased significantly with $15 \mathrm{t} \mathrm{ha}^{-1}$ dose. Again, B4 showed the most pronounced effect (Table 2). The diameter of the sunflower head increased slightly $(\leq+15 \%)$ due to biochar amendment (Table 2$)$. This response was also observed by Tatarková et al. (2013) and Alburquerque et al. (2014). Nevertheless, the present results contrast with those recently reported by De la Rosa et al. (2014), which showed a significant increase of the biomass production of Lolium perenne caused by biochar application in pot experiments performed with the same Calcic Cambisol and the same biochars as they were used in the present study. However, in the former study, the experiment was performed with higher biochar doses and under greenhouse conditions with optimal water irrigation. In this work, B3, B2 and $\mathrm{B} 1$ treatments yielded much greater plant biomass than the B4 amendment. This response was attributed to the greater content of nutrients of B3 and the very high specific surface area (SSA) of B1 and B2. It is known that large SSA of biochars promotes adhesion and cohesion between biochar and water, which can increase water retention (Dempster et al., 2012). However, this may be due to the detriment of non-irrigated crops growing under field conditions when water turns to be a limiting factor during the hot late spring and summer period of the Mediterranean regions. Under those circumstances, the plant and the biochar are likely to compete for water and the biochar with the smallest SSA (B4) may have released more plant available water than the other biochars with larger SSA.

The number of leaves per plant as well as the leaf area (LA) per plant at both biochar doses are shown in Table 2 and Fig. 2 respectively. A larger number of leaves has been positively associated with growth in different species (Poorter and Remkes, 1990). The amendment of $1.5 \mathrm{t} \mathrm{ha}^{-1}$ of biochar did not significantly alter the number of leaves and the total LA compared with the plants of the control plot. In contrast, $15 \mathrm{t} \mathrm{ha}^{-1}$ amended plants showed more

Table 2

Values of emerged plants, stem diameter, head diameter, number of leaves and grams of sunflower seeds produced per plant.

\begin{tabular}{|c|c|c|c|c|c|c|c|c|c|c|c|c|c|c|c|c|}
\hline Dose & Treatment & $\begin{array}{l}\text { Emerged } \\
\text { plants (\%) }\end{array}$ & S.D. & & $\begin{array}{l}\text { Stem } \\
\text { diameter }(\mathrm{cm})\end{array}$ & S.D. & & $\begin{array}{l}\text { Head } \\
\text { diameter }(\mathrm{cm})\end{array}$ & S.D. & & $\begin{array}{l}\text { No leaves } \\
\text { per plant }\end{array}$ & S.D. & & $\begin{array}{l}\text { Grams of sunflower } \\
\text { seeds per plant }\end{array}$ & S.D. & \\
\hline \multirow[t]{5}{*}{$1.5 \mathrm{tha}^{-1}$} & Control & 95.8 & \pm 10.2 & $\mathrm{a}$ & 2.60 & \pm 0.40 & $\mathrm{a}$ & 21.5 & \pm 1.7 & $\mathrm{a}$ & 30.0 & \pm 1.5 & a & 152.5 & \pm 24.3 & $\mathrm{a}$ \\
\hline & B1 & 91.7 & \pm 8.3 & $\mathrm{a}$ & 2.36 & \pm 0.20 & $\mathrm{a}$ & 18.5 & \pm 2.4 & $\mathrm{~b}$ & 32.6 & \pm 1.2 & a & 150.7 & \pm 19.6 & $\mathrm{a}$ \\
\hline & B2 & 91.7 & \pm 8.5 & $\mathrm{a}$ & 1.86 & \pm 0.21 & $\mathrm{a}$ & 17.4 & \pm 1.8 & c & 27.6 & \pm 2.0 & a & 160.0 & \pm 21.8 & $\mathrm{a}$ \\
\hline & B3 & 91.7 & \pm 5.3 & $\mathrm{a}$ & 2.34 & \pm 0.16 & $\mathrm{a}$ & 20.3 & \pm 3.1 & $a b$ & 29.8 & \pm 1.5 & a & 125.4 & \pm 12.5 & $\mathrm{a}$ \\
\hline & B4 & 83.3 & \pm 9.3 & $\mathrm{a}$ & 2.18 & \pm 0.13 & $\mathrm{a}$ & 19.4 & \pm 2.6 & $\mathrm{ab}$ & 29.7 & \pm 1.4 & $\mathrm{a}$ & 147.8 & \pm 17.4 & $\mathrm{a}$ \\
\hline \multirow[t]{5}{*}{$15 \mathrm{tha}^{-1}$} & Control & 91.7 & \pm 8.3 & $\mathrm{a}$ & 2.40 & \pm 0.70 & $\mathrm{~b}$ & 20.6 & \pm 2.5 & $\mathrm{~b}$ & 23.8 & \pm 1.9 & $\mathrm{~b}$ & 137.2 & \pm 35.0 & $\mathrm{~b}$ \\
\hline & B1 & 91.7 & \pm 5.3 & $\mathrm{a}$ & 3.24 & \pm 0.15 & $a b$ & 23.6 & \pm 2.3 & $a b$ & 26.3 & \pm 1.8 & $\mathrm{~b}$ & 150.5 & \pm 11.9 & $\mathrm{~b}$ \\
\hline & B2 & 100.0 & \pm 3.0 & $\mathrm{a}$ & 3.38 & \pm 0.26 & $a b$ & 20.6 & \pm 3.3 & $a b$ & 28.7 & \pm 1.6 & $\mathrm{ab}$ & 159.2 & \pm 23.6 & $\mathrm{~b}$ \\
\hline & B3 & 91.7 & \pm 5.3 & $\mathrm{a}$ & 3.42 & \pm 0.30 & $a b$ & 24.4 & \pm 2.6 & $\mathrm{a}$ & 28.7 & \pm 0.7 & $\mathrm{ab}$ & 217.0 & \pm 21.5 & $a b$ \\
\hline & B4 & 95.8 & \pm 4.2 & $\mathrm{a}$ & 3.84 & \pm 0.19 & $\mathrm{a}$ & 23.6 & \pm 1.4 & $\mathrm{ab}$ & 32.7 & \pm 1.2 & $\mathrm{a}$ & 260.2 & \pm 12.6 & $\mathrm{a}$ \\
\hline
\end{tabular}

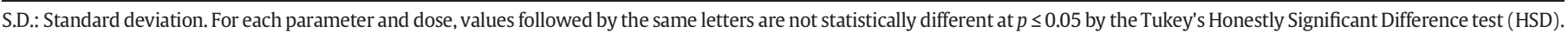


A)

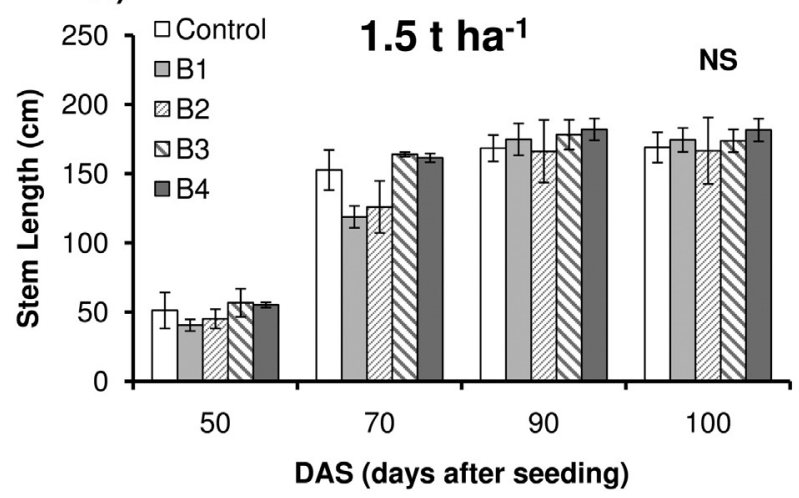

B)

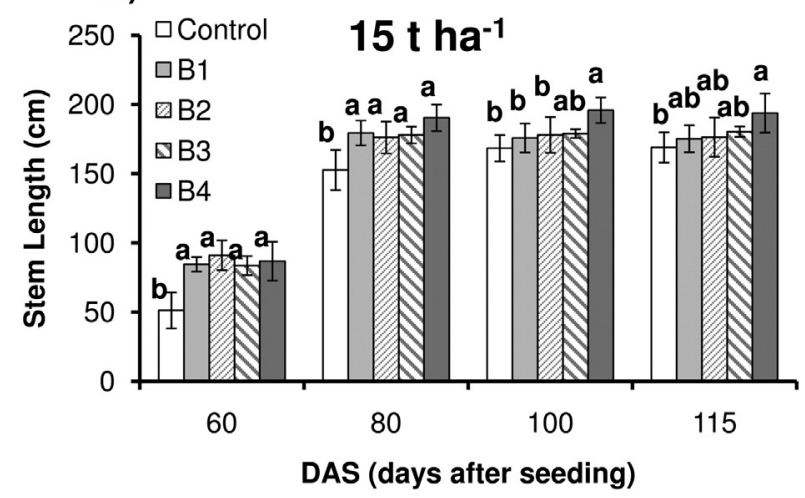

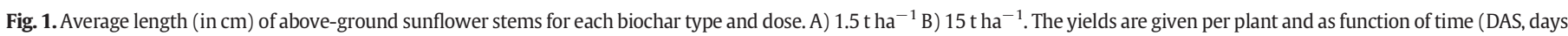
after seeding). The error bars show the mean \pm standard error.
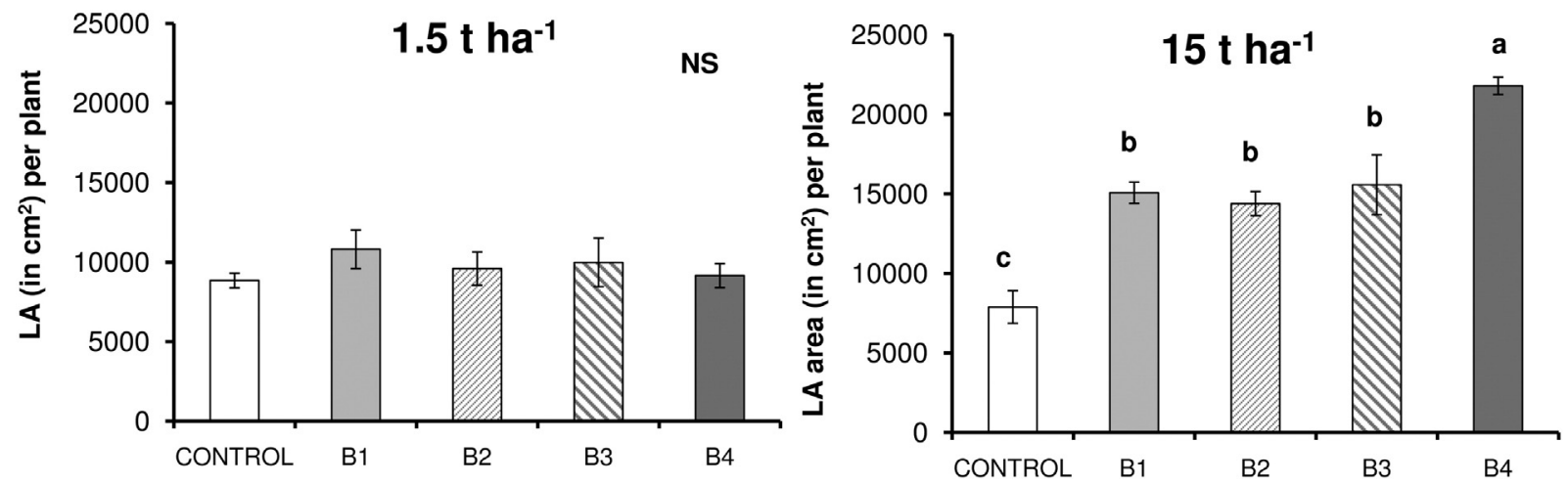

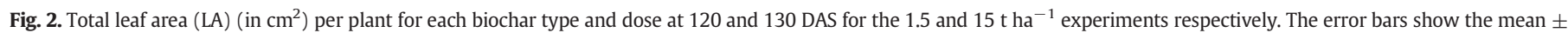
standard error.

leaves and a higher LA than the control plants (as seen in Alburquerque et al., 2014). Here, too, B4 amended plots exhibited the highest yields of all treatments.

\subsubsection{Sunflower productivity}

The soils with a biochar-application rate of $1.5 \mathrm{tha}^{-1}$ resulted in similar productivity than the control soils ( 140 to $150 \mathrm{~g}$ of sunflower seeds per plant; Table 2), which is in agreement with the meta-analysis developed by Jeffery et al. (2011), suggesting that applying biochars doses below $5 \mathrm{t} \mathrm{ha}^{-1}$ does not generate consistent yield increases.

The biochar-application rate of $15 \mathrm{t} \mathrm{ha}^{-1}$ increased seed production in the case of B3 and significantly with B4. Consequently biochars with the lowest SSA (See Supplementary Table ST2) and lower cohesion between biochar and water (B3 and B4) were more productive for the sunflower plantation under the Mediterranean climate and without additional water irrigation. Moreover, taking into account that B3 contained the largest amount of ash and nutrients (De la Rosa et al., 2014; Supplementary Table ST2), the higher productivity and better development of the plants of the B4 amended plots could indicate that under the given experimental conditions water availability could be a more determinant factor than the additional input of nutrients due to biochar application.

\subsection{Effects of biochar amendment on plant physiology parameters}

\subsubsection{Efficiency of Photosystem-II}

The efficiency of Photosystem-II (PSII), also called quantum yield (QY $\mathrm{PSII}_{\text {II }}$, is a well-known stress marker. It is related to the water status of the plant (Van Kooten and Snel, 1990), and is reduced under drought stress (Maxwell and Johnson, 2000). Biochar application determined higher $\mathrm{QY}_{\mathrm{PSII}}$ in sunflower plants and the response was proportional to the dose employed. Therefore, greater differences between treated and untreated plants are observed in $15 \mathrm{t} \mathrm{ha}^{-1}$ amendments (Fig. 3). After 90, 100 and 105 DAS, plants did not exhibit stress values in any experiment (1.5 and $15 \mathrm{t} \mathrm{ha}^{-1}$; Fig. $3 \mathrm{a}$ and $\mathrm{b}$, respectively). The obtained QY $_{\text {PSII }}$ values ranged between 72 and $77 \%$ in the experiment with biochar dose of $1.5 \mathrm{t} \mathrm{ha}^{-1}$, and between 65 and $78 \%$ in that with $15 \mathrm{t} \mathrm{ha}^{-1}$. Values between 70 and $80 \%$ correspond to non-stressed (well-watered) sunflower plants (Cechin et al., 2006 and Ghaffari et al., 2012), tobacco plants (Franco-Navarro et al., 2016) or Olea europaea (Boughalleb and Hajlaoui, 2011) among other Mediterranean species. Reductions of QY PSII values were observed at 115 DAS. This depletion can be related with the higher temperature and water shortage due to the advance of the summer season (warmer and dry; Supplementary Table ST1). Interestingly, under these conditions, $15 \mathrm{t} \mathrm{ha}^{-1}$ biochar treatments exacerbated the differences with control plants. Whereas plants from un-amended plots exhibited higher stress symptoms ( $\mathrm{QY}_{\mathrm{PSII}}$ value around 63\%), amended plants showed significantly higher stability of PSII (Fig. 3b), with the B3 biochar presenting the highest QY value.

\subsubsection{Stomatal conductance $\left(g_{s}\right)$ (leaf transpiration)}

Fig. 4 clearly shows that biochar reduced stomatal conductance in both 1.5 and $15 \mathrm{t} \mathrm{ha}^{-1}$ treatments. Therefore, the biochar-dose dependence previously observed on plant growth parameters was not observed in the present study, with the $1.5 \mathrm{t} \mathrm{ha}^{-1}$ treatment resulting in similar $g_{s}$ reductions than the $15 \mathrm{t} \mathrm{ha}^{-1}$ treatment. In $C_{3}$ plants, such as sunflower, an increase of LA was associated to a decrease of stomatal conductance (Ocheltree et al., 2014). More recently, it was demonstrated that chloride-induced increase of leaf cell size resulted in higher LA 
A)

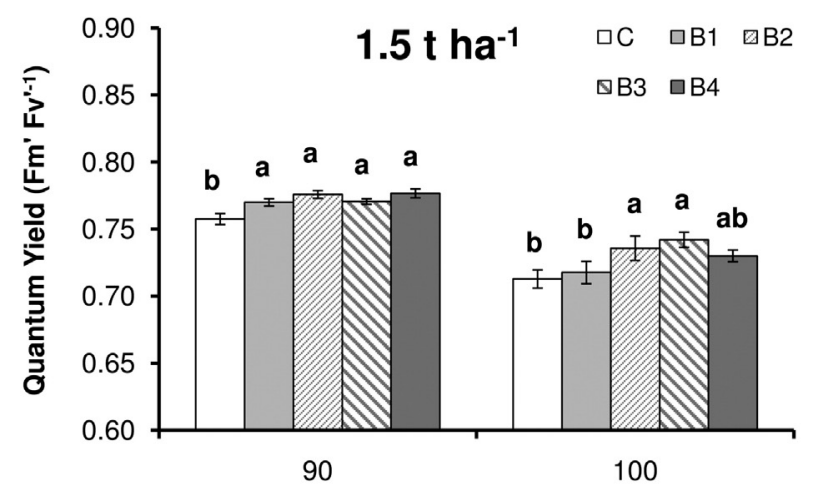

DAS (days after seeding)
B)

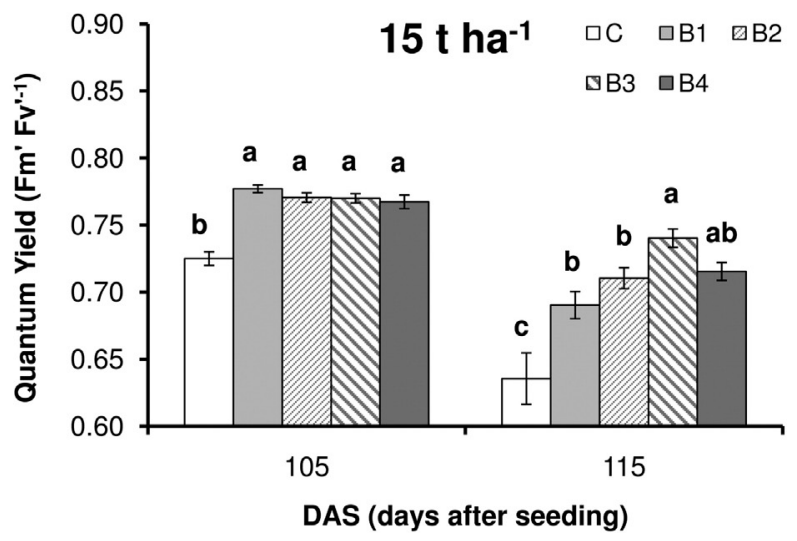

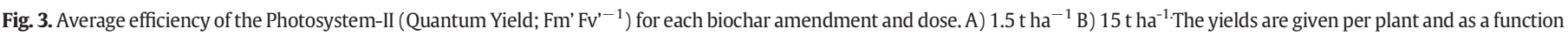
of time (DAS). The error bars show the mean \pm standard error.

A)

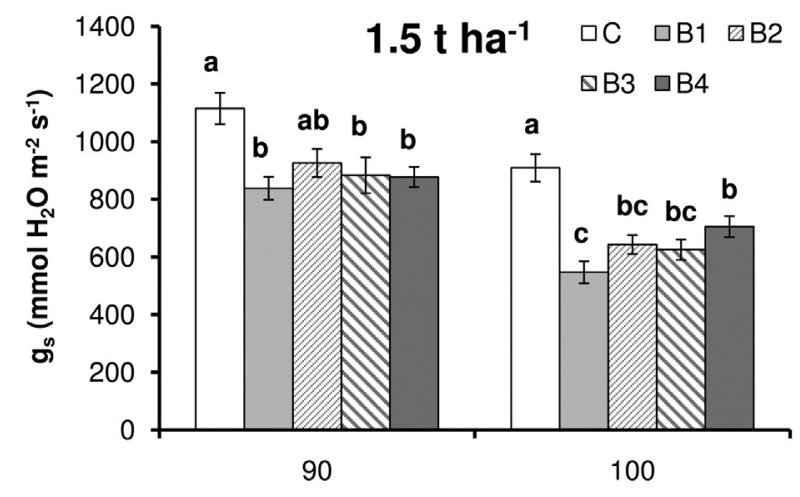

DAS (days after seeding)
B)

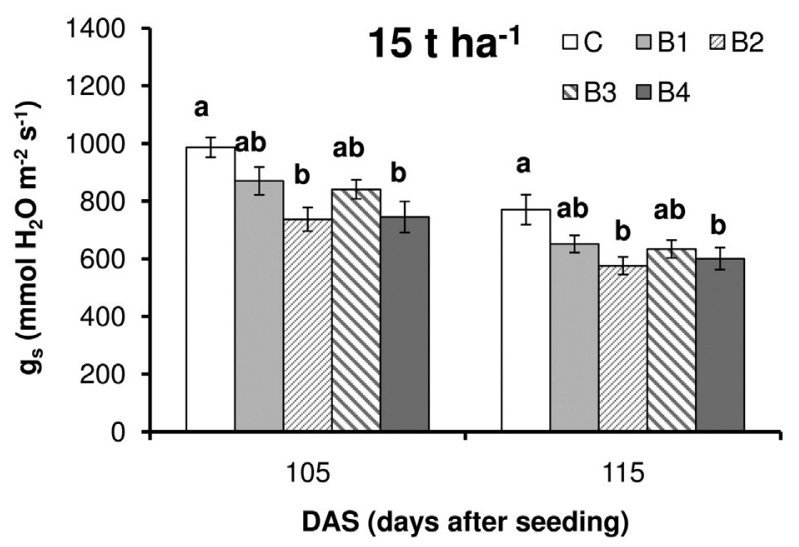

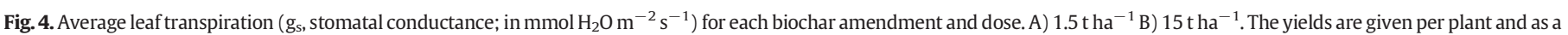
function of time (DAS). The error bars show the mean \pm standard error.

and reduced $g_{s}$ (Franco-Navarro et al., 2016) due to a reduction in stomatal frequency (Colmenero-Flores personal communication). This resulted in higher water use efficiency and drought tolerance (FrancoNavarro et al., 2016). However, in the present study, no clear correlation could be established between biochar-induced LA stimulation and $g_{s}$ response after application of biochar (see Supplementary Fig. SA), thus $g_{s}$ reduction was evident (Fig. 4a) but it was not a consequence of LA increase (Fig. 2b). It has been proposed that water retention capacity of biochar can reduce root water availability and induce additional water deficit to the plants (Abel et al., 2013), which may react with the observed stomatal closure. If this hypothesis is true, a dose-dependent response is expected and the application of $15 \mathrm{t}$ biochar ha ${ }^{-1}$ would lead to a much stronger stress responses than the $1.5 \mathrm{t} \mathrm{ha}^{-1}$ treatment. On the one hand, not only this response was not observed (Fig. 4), but the biochar-amended plants exhibited reduced stress symptoms (Fig. 3 ) and higher growth (Table 2) compared to un-amended plants. On the other hand, positive impacts of biochar application on the relationship between plant and water due to increased availability of water for the plants have been reported (Baronti et al., 2014). However, higher water availability leads to better hydrated plants with greater capacity for stomatal opening, which is again opposed to our observations. Therefore, we hypothesize that biochar addition to soils alters anatomical and/or physiological parameters of the plants that in turn reduces stomatal conductance and increases water use efficiency of sunflower plants. Since the last rain on the crop, increasing drought and water deficit in the field became apparent through a progressive reduction of $g_{s}$ in control plants (Supplementary Fig. SB). Under these conditions, a more efficient use of water increased drought tolerance of amended plants, allowing better growth and crop performance. Therefore, we propose that biochar amendment provides protection from water deficit stress, a finding that points to the agronomic relevance of biochar use on Mediterranean rainfed crops.

\section{Conclusions}

One of the objectives of our study was to introduce the innovative photosynthetic and physiological parameters for studying the impact of biochar amendments on plant physiology. By this approach we demonstrated that plant physiological issues should not be neglected for an appropriate elucidation of the suitability of biochars for soil improvement.

Our results verified that the amendment of a Calcic Cambisol with $1.5 \mathrm{t}$ biochar ha ${ }^{-1}$ did not modify significantly soil properties and sunflower morphology, nor did it affect the agronomic productivity of sunflowers. On the contrary, increasing the amount biochar to $15 \mathrm{tha}^{-1}$ altered those parameters, although the extent of it depended on the type of biochar. Application of B4, a vineyard-wood derived biochar with an extremely low specific surface area (SSA) caused a significant improvement of the plant development and productivity. In addition, B4 amendment yielded in larger LA and caused no-stress symptoms of 
plants. We hypothesize that the low SSA of B4 compared with the other biochars probably provided more water available to the plants during the dry period. Thus, large SSA combined with the high WHC of B1 and B2 may have increased the competition for water which cuts down the potentially positive effect of biochar amendment. Our study strongly points to the conclusion that surficial properties of biochars, specially their capacity of retaining water including the strength of cohesion between biochar and water, are of key importance during the development of sunflowers under field conditions. They are probably responsible for the reduction of the leaf transpiration of plants on biochar amended soils; without that, their growth and biomass production had been reduced. In the next future, it may be worth to explore other parameters such as the leaf ion content, the frequency of stomatal cells and net photosynthetic rate in leaves, in order to obtain a better understanding of the correlation between biochar amendments and reduced stomatal conductance in plants.

Finally, the fact that results of this field study are in contrast to those reported previously by several authors, evidences that effects of biochar amendment tested under greenhouse conditions cannot be unambiguously extrapolated to the field. This is in particular true for regions with highly varying climate conditions such as the Mediterranean area. Although not tested in the present work, one has to bear in mind that difference in soil properties can lead to additional variability.

Supplementary data to this article can be found online at http://dx. doi.org/10.1016/j.catena.2016.07.037.

\section{Acknowledgments}

The Marie Skłodowska-Curie actions of the European Union's FP7 People Programme (REA grant agreement no PCIG12-GA-2012333784-Biocharisma project) and the Spanish Ministry of Economy and Competitiveness (MINECO) (project PCGL2012-37041) are thanked for the financial support of the present study. The Spanish Ministry of Education, Culture and Sport is acknowledged for funding the FPU fellowship (FPU 13/05831) of Marina Paneque, and the contract of Juan De Dios Franco-Navarro (AGL2009-08339/AGR). The European Biochar Network (Biochar as option for sustainable resource managementCOST action TD1107) and Bodegas Torres (Spain) are acknowledged for providing the biochar samples. M. Velasco is gratefully acknowledged for her technical assistance at field.

\section{References}

Abel, S., Peters, A., Trinks, S., Schonsky, H., Facklam, M., Wessolek, G., 2013. Impact of biochar and hydrochar addition on water retention and water repellency of sandy soil. Geoderma 202-203, 183-191.

Abiven, S., Hund, A., Martinsen, V., Cornelissen, G., 2015. Biochar amendment increases maize root surface areas and branching: a shovelomics study in Zambia. Plant Soil 395, 45-55.

Alburquerque, J.A., Calero, J.M., Barrón, V., Torrent, J., Del Campillo, M.C., Gallardo, A., Villar, R., 2014. Effects of biochars produced from different feedstocks on soil properties and sunflower growth. J. Plant Nutr 177, 16-25.

Alburquerque, J.A., Salazar, P., Barrón, V., Torrent, J., Del Campillo, M.C., Gallardo, A., Villar R., 2013. Enhanced wheat yield by biochar addition under different mineral fertilization levels. Agron. Sustain. Dev 33, 475-484.

Almendros, G., González-Vila, F.J., 2012. Wildfires, soil carbon balance and resilient organic matter in Mediterranean ecosystems. A review. Span. J. Soil Sci. 2, 8-33.

Bachmann, H.J., Bucheli, T.D., Dieguez-Alonso, A., Fabbri, D., Knicker, H., Schmidt, H.P., Ulbricht, A., Becker, R., Buscaroli, A., De la Rosa, J.M., Sakrabaniu, R., Sohi, S., Soja, G., Valagussa, M., Verheijen, F., Zehetner, F., 2016. Towards the standardization of biochar analysis: the COST Action TD1107 inter-laboratory comparison. J. Agric. Food Chem. 64, 513-527.

Baronti, S., Vaccari, F.P., Miglietta, F., Calzolari, C., Lugato, E., Orlandini, S., Pini, R., Zulian, C. Genesio, L., 2014. Impact of biochar application on plant water relations in Vitis vinifera (L.). Eur. J. Agron 53, 38-44.

Blackwell, P., Riethmuller, G., Collins, M., 2009. Biochar application to soil. In: Lehmann, J., Joseph, S. (Eds.), Biochar for Environmental Management: Science and Technology, second ed. Earthscan, London, pp. 207-226.

Borchard, N., Siemen, J., Ladd, B., Möller, A., Amelung, W., 2014. Application of biochars to sandy and silty soil failed to increase maize yield under common agricultural practice. Soil Tillage Res. 144, 184-194.
Boughalleb, F., Hajlaoui, H., 2011. Physiological and anatomical changes induced by drought in two olive cultivars (cv Zalmati and Chemlali). Acta Physiol. Plant. 33, 53-65.

Cayuela, M.L., Van Zwieten, L., Singh, B.P., Jeffery, S., Roig, A., Sanchez-Monedero, M.A. 2014. Biochar's role in mitigating soil nitrous oxide emissions: a review and metaanalysis. Agric. Ecosyst. Environ. 191, 5-16.

Cechin, I., Rossi, S.C., Oliveira, V.C., Fumis, T.F., 2006. Photosynthetic responses and proline content of mature and young leaves of sunflower plants under water deficit. Photosynthetica 44, 143-146.

De la Rosa, J.M., Paneque, M., Hilber, I., Blum, F., Knicker, H., Bucheli, T.D., 2016. Assessment of polycyclic aromatic hydrocarbons in biochar and biochar-amended agricultural soil from Southern Spain. J. Soils Sediments 16, 557-565.

De la Rosa, J.M., Paneque, M., Miller, A.Z., Knicker, H., 2014. Relating physical and chemical properties of four different biochars and their application rate to biomass production of Lolium perenne on a Calcic Cambisol during a pot experiment of 79 days. Sci. Total Environ. 499, 175-184.

Dempster, D.N., Jones, D.L., Murphy, D.V., 2012. Clay and biochar amendments decreased inorganic but not dissolved organic nitrogen leaching in soil. Soil Res. 50, 216-221.

Downie, A., Crosky, A., Munroe, P., 2009. Physical properties of biochar. In: Lehmann, J. Joseph, S. (Eds.), Biochar for Environmental Management: Science and Technology, second ed. Earthscan, London, pp. 13-32.

Environment Protection Authority (EPA), 1991. Guidelines for Wastewater Irrigation, Publication 168. Environment Protection Authority, Melbourne.

Franco-Navarro, J.D., Brumós, J., Rosales, M.A., Cubero-Font, P., Talón, M., ColmeneroFlores, J.M., 2016. Chloride regulates leaf cell size and water relations in tobacco plants. J. Exp. Bot. 67, 873-891. http://dx.doi.org/10.1093/jxb/erv502.

Genesio, L., Miglietta, F., Baronti, S., Vaccari, F.P., 2015. Biochar increases vineyard productivity without affecting grape quality: results from a four years field experiment in Tuscany. Agric. Ecosyst. Environ. 201, 20-25.

Ghaffari, M., Toorchi, M., Valizadeh, M., Shakiba, M.R., 2012. Morpho-physiological screening of sunflower inbred lines under drought stress condition. Turk. J. Field Crops 17, 185-190.

Hossain, M.K., Strezo, V., Chan, K.Y., Ziolkowski, A., Nelson, P.F., 2011. Influence of pyrolysis temperature on production and nutrient properties of wastewater sludge biochar. J. Environ. Manag. 92, 223-228.

Jeffery, S., Abalos, D., Spokas, K.A., Verheijen, F.G.A., 2015a. Biochar effects on crop yield In: Lehmann, J., Joseph, S. (Eds.), Biochar for Environmental Management: Science and Technology, second ed. Earthscan, London, pp. 301-326.

Jeffery, S., Meinders, M.B.J., Stoof, C.R., Bezemer, T.M., van de Voorde, T.F.J., Mommer, L., van Groenigen, J.W., 2015b. Biochar application does not improve the soil hydrological function of a sandy soil. Geoderma 251-252, 47-54.

Jeffery, S., Verheijen, F.G.A., van der Velde, M., Bastos, A.C., 2011. A quantitative review of the effects of biochar application to soils on crop productivity using meta-analysis. Agric. Ecosyst. Environ. 144, 175-187.

Jones, D.L., Rousk, J., Edwards-Jones, G., DeLuca, T.H., Murphy, D.V., 2011. Biochar-mediated changes in soil quality and plant growth in a three year field trial. Soil Biol. Biochem 45, 113-124.

Kammann, C.I., Linsel, S., Gößling, J.W., Koyro, H.W., 2011. Influence of biochar on drought tolerance of Chenopodium quinoa Willd and on soil-plant relations. Plant Soil 345 195-210.

Laird, D.A., Fleming, P., Davis, D.D., Horton, R., Wang, B., Karlen, D.L., 2010. Impact of biochar amendments on the quality of a typical Midwestern agricultural soil. Geoderma $158,443-449$

Lehmann, J., Joseph, S., 2009. Biochar for environmental management: science and technology. first ed. Earthscan, London.

Lehmann, J., Joseph, S., 2015. Biochar for Environmental Management: Science and Technology. second ed. Earthscan, London.

Lehmann, J., Gaunt, J., Rondon, M., 2006. Bio-char sequestration in terrestrial ecosystems a review. Mitig. Adapt. Strateg. Glob. 11, 395-419.

Li, X., Shen, Q., Zhang, D., Mei, X., Ran, W., Xu, Y., Yu, G., 2013. Functional groups determine biochar properties ( $\mathrm{pH}$ and EC) as studied by two-dimensional ${ }^{13} \mathrm{C}$ NMR correlation spectroscopy. PLoS One 8 (6), e65949. http://dx.doi.org/10.1371/journal.pone. 0065949.

Liu, Z., Chen, X., Jing, Y., Li, Q., Zhang, J., Huang, Q., 2014. Effects of biochar amendment on rapeseed and sweet potato yields and water stable aggregate in upland red soil. Catena $123,45-51$.

Magrama, 2015. Spanish Ministry of Agriculture and Environment. http://www magrama.gob.es/es/agricultura/temas/produccionesagricolas/cultivos-herbaceos/ leguminosas-y-oleaginosas/\#para9 (Accessed. 10th June 2015).

Maxwell, K., Johnson, G.N., 2000. Chlorophyll fluorescence-a practical guide. J. Exp. Bot 51, 659-668.

Mudarra-Gómez, J.L., 1988. Reconocimiento de los suelos de la comarca de El Aljarafe (Sevilla). IRNAS-CSIC.

Mukherjee, A., Lal, R., Zimmerman, A.R., 2014. Effects of biochar and other amendments on the physical properties and greenhouse gas emissions of an artificially degraded soil. Sci. Total Environ. 487, 26-36.

Novak, J.M., Busscher, W.J., 2013. Selection and Use of Designer Biochars to Improve Characteristics of Degraded Soils. In: Lee, J.W. (Ed.), Advanced Biofuels and Bioproducts. Springer, New York, pp. 69-96.

Obia, A., Mulder, J., Martinsen, V., Cornelissen, G., Børresen, T., 2016. In situ effects of biochar on aggregation, water retention and porosity in light-textured tropical soils. Soil Tillage Res. 155, 35-44.

Ocheltree, T.W., Nippert, J.B., Prasad, P.V.V., 2014. Stomatal responses to changes in vapor pressure deficit reflect tissue-specific differences in hydraulic conductance. Plant Cel Environ 37, 132-139.

Ojeda, G., Mattana, S., Ávila, A., Alcañiz, J.M., Volkman, M., Bachmann, J., 2015. Are soilwater functions affected by biochar application? Geoderma 249-250, 1-11. 
Poorter, H., Remkes, C., 1990. Leaf area ratio and net assimilation of 24 wild species differing in relative growth rate. Oecologia 83, 553-559.

Romanya, J., Rovira, P., 2011. An appraisal of soil organic C content in Mediterranean ag ricultural soils. Soil Use Manag. 27, 321-332.

Rouphael, Y., Colla, G., Fanasca, S., Karam, F., 2007. Leaf area estimation of sunflower leaves from simple linear measurements. Photosynthetica 45, 306-308.

Schultz, H., Glaser, B., 2012. Effects of biochar compared to organic and inorganic fertilizers on soil quality and plant growth in a greenhouse experiment. J. Plant Nutr. Soil Sci 175, 410-422.

Schultz, H., Dunst, G., Glaser, B., 2013. Positive effects of composted biochar on plant growth and soil fertility. Agron. Sustain. Dev 33, 817-827.

Sohi, S.P., Krull, E., Lopez-Capel, E., Bol, R., 2010. A review of biochar and its use and function in soil. Adv. Agron 105, 47-82.

Soil Survey Division Staff, 1993. Soil Survey Manual. Soil Conservation Service. U.S. Department of Agriculture Handbook 18

Tatarková, V., Hiller, E., Vaculík, M., 2013. Impact of wheat straw biochar addition to soil on the sorption, leaching, dissipation of the herbicide (4-chloro-2-methylphenoxy) acetic acid and the growth of sunflower (Helianthus annuus L.) Ecotox. Environ. Saf. 92, 215-221.

Uzoma, K.C., Inoue, M., Andry, H., Zahoor, A., Nishihara, E., 2011. Influence of biochar application on sandy soil hydraulic properties and nutrient retention. J. Food Agric. Environ. 9, 1137-1143.
Vaccari, F.P., Maienza, A., Miglietta, F., Baronti, S., Di Lonardo, S., Giagnoni, L., Lagomarsino, A., Pozzi, A., Pusceddu, E., Ranieri, R., Valboa, G., Genesio, L., 2015. Biochar stimulates plant growth but not fruit yield of processing tomato in a fertile soil. Agric. Ecosyst. Environ. 207, 163-170.

Van Kooten, O., Snel, J.H., 1990. The use of chlorophyll fluorescence nomenclature in plant stress physiology. Photosynth. Res. 25, 147-150.

Van Zwieten, L., Singh, B., Joseph, S., Kimber, S., Cowie, A., Chan, K.Y., 2009. Biochar and emissions of non- $\mathrm{CO}_{2}$ greenhouse gases from soil. In: Lehmann, J., Joseph, S. (Eds.), Biochar for Environmental Management. Earthscan, London, pp. 227-249.

Veihmeyer, F.J., Hendrickson, A.H., 1931. The moisture equivalent as a measure of the field capacity of soils. Soil Sci 32, 181-193.

WRB World Reference Base Working group, 2007. In World Soil Resources Reports. 103. FAO, Rome.

Zaho, L., Cao, X., Masek, O., Zimmerman, A., 2013. Heterogeneity of biochar properties as a function of feedstock sources and production temperatures. J. Hazard. Mater. 256257, 1-9.

Zhao, X., Wang, J., Wang, S., Xing, G., 2014. Successive straw biochar application as a strategy to sequester carbon and improve fertility: a pot experiment with two rice/wheat rotations in paddy soil. Plant Soil 378, 279-294. 